\title{
Risk factors and current health- seeking patterns of migrants in northeastern Mexico: healthcare needs for a socially vulnerable population
}

\section{Philippe Stoesslé ${ }^{*}$, Francisco González-Salazar ${ }^{2,3}$, Jesús Santos-Guzmán ${ }^{4}$ and Nydia Sánchez-González ${ }^{5}$}

${ }^{1}$ Department of Social Sciences, University of Monterrey, Monterrey, Mexico, ${ }^{2}$ Mexican Social Security Institute (IMSS), Monterrey, Mexico, ${ }^{3}$ Department of Basic Sciences, University of Monterrey, Monterrey, Mexico, ${ }^{4}$ School of Medicine, Monterrey Institute of Technology and Higher Education, Monterrey, Mexico, ${ }^{5}$ Faculty of Nutrition and Public Health, Autonomous University of Nuevo León, Monterrey, Mexico

OPEN ACCESS

Edited by:

Jill Eileen Guernsey De Zapien, University of Arizona Mel and Enid Zuckerman College of Public Health,

USA

Reviewed by: Armin D. Weinberg, Life Beyond Cancer Foundation, USA Anna Ochoa O'Leary, University of Arizona, USA

*Correspondence:

Philippe Stoesslé,

Department of Social Sciences, University of Monterrey (UDEM), Av. Morones Prieto 4500 Pte., San Pedro Garza García 66238, Mexico philippe.stoessle@udem.edu

Specialty section: This article was submitted to Public Health Education and Promotion, a section of the journal Frontiers in Public Health

Received: 20 March 2015

Accepted: 22 July 2015

Published: 06 August 2015

Citation:

Stoesslé P, González-Salazar F,

Santos-Guzmán J and

Sánchez-González N (2015) Risk factors and current health-seeking patterns of migrants in northeastern Mexico: healthcare needs for a socially vulnerable population.

Front. Public Health 3:191. doi: 10.3389/fpubh.2015.00191
This study identified risk factors for health and access to healthcare services of migrants during their journey across Mexico to the United States. Data were collected in shelters located in Monterrey, the largest city of northeastern Mexico, through a basic clinical examination and a survey completed by 75 migrants; 92\% of them were undocumented Central Americans. During their transit, they are at a high risk of contracting, developing, and transmitting diseases. The need of working to survive affects health-seeking behavior and a constant fear of being traced keeps migrants away from public health services, which delays diagnosis and treatment of diseases. Negligent lifestyles, such as smoking, drinking (31.8\% of men and $11.1 \%$ of women), and drug abuse (13\% of men and $11 \%$ of women), were found. Regarding tuberculosis (TB), undocumented migrants are usually not screened, even though they come from countries with a high TB burden. Besides, they might be overexposed to TB because of their living conditions in overcrowded places with deficient hygiene, protection, and malnutrition (54.7\% of the sample). Possible comorbidities like acquired immune deficiency syndrome (AIDS; 4\%) and diabetes (2.7\%, but probably under-diagnosed) were referred. Migrants have little TB knowledge, which is independent of their level of education or a previous experience of deportation. About one-third of the migrants were totally unfamiliar with TB-related symptoms, while $36 \%$ had correct knowledge of basic TB symptoms. We conclude that a shortage of information on the highly vulnerable migratory population combined with a lack of social support and health education among migrants may play a significant role in the spread of communicable diseases. We recommend that health authorities address this urgent, binational, public health concern in order to prevent outbreaks of emerging infections.

Keywords: risk factors, undocumented migrants, social vulnerability, tuberculosis knowledge and perceptions, barriers to health

\footnotetext{
Abbreviations: AIDS, acquired immune deficiency syndrome; BCG, Bacillus Calmette-Guérin; DM, diabetes mellitus; HIV, human immunodeficiency virus infection; INM, National Institute of Migration; KAP, knowledge, attitude and practices; NGO, no governmental organization; SD, standard deviation; TB, tuberculosis; US, United States; WHO, World Health Organization.
} 


\section{Introduction}

In 2013, 214 million migrants lived for at least 1 year in a country different from their home country (representing 3.1\% of the world population), against 150 million migrants in 2000 (1). Apart from a rapidly increasing migration number, migration also involves a wider diversity of cultural groups. About 82 million people per year migrate from a developing country to a developed one. Furthermore, the latest estimations suggest that around one-third of migration from developing countries could be irregular (2). With migration being a growing tendency, migrants experience a unique diversity in health needs and profiles.

Worldwide, migrants are more vulnerable than nationals, as they have fewer rights than people with a citizenship. In Mexico, the life style, journey, and work of migrants, especially the undocumented migrants from Central and South America, lead to considerable risks to personal, physical, and mental well-being (3-5). Migrants' well-being is further compromised by irregular access to social and health services, immigrant status, and a prevailing anti-migrant attitude of the general public (6-8). Indeed, legal and practical obstacles limit access to health services on both sides of the Mexican-United States (US) border, and the consequential late detection of illnesses negatively affects the health of immigrants (9).

Transnational migration through Mexico affects the public health situation by connecting areas with diverse disease prevalence and other socioeconomic factors. Most of these health issues represent challenges for the limited territorial public health systems, because migrants are by definition mobile and hard-to-reach persons. Thus, the interest of our research is to determine to what extent the migration process affects the health of both the migrants and the general population. Hereto, the present pilot study aims to identify the risk factors of illnesses among migrants, as well as to get insight into the health-seeking patterns and TB knowledge among North, Central, and South American (im)migrants who pass through the city of Monterrey, Mexico, in their quest to reach the US. To our knowledge, this is the first report on current patterns of migration and their impact on health in this specific population in northeastern Mexico. Our results provide a basis for rethinking the specific healthcare needs in order to protect the health status of the general population.

\section{Materials and Methods}

This study is an observational, transversal, and descriptive study realized from September 1st to November 30th, 2014, at temporary shelters for migrants in Monterrey. Data were collected through a basic clinical examination and a survey.

\section{Population Definition}

We adopted the definition of the International Organization for Migration's definition for "undocumented immigrants": "Persons who change their place of usual residence" but without having a legal residence situation (10).

\section{Ethics and Consent}

The research protocol followed principles of the Declaration of Helsinki and was approved by the University of Monterrey under the project code UIN15012. Written informed consent was obtained from all participants. In case of minors, informed consent was obtained from the parents or accompanying adults. No unaccompanied minor participated in the study.

\section{Sample}

The sample consisted of 75 temporal immigrant volunteers of any age and gender who attended one of the two migrant shelters managed by the Catholic Church in the Monterrey Metropolitan Area; the "Centro de Apostolado San Nicolás de Tolentino - CasaNicolás" and the "Casa Santa Martha." It is important to underline that in México the shelters for undocumented migrants are mostly managed by different churches, the majority of them were managed by the Catholic Church. Rather than realizing evangelization, these shelters provide help and assistance to the (im)migrants. They do this independent of their religious beliefs or those of the migrants. Therefore, we consider that the formal religious characteristic of the shelters does not affect the origin or representativeness of the population sample.

Subjects with incomplete information or immigrants who dropped out the study before completion were not considered. The sample encompassed 71 undocumented South and Central American immigrants and 4 North Americans. We decided to include the latter because they complied with the definition of migrant and suffered the same mental and physical health stressors and social vulnerability similar to undocumented immigrants (11) (Table 1).

\section{Sampling Location}

Monterrey is a cosmopolitan city located in northeastern Mexico and is the capital city of the state of Nuevo Leon. Over 4.4 million people live in this metropolitan area. It is one of the most important cities of the country and it represents one of the traditional routes of migrants coming from southern states of Mexico and from the other Central and South American countries (12).

\section{The Questionnaire}

Our team, which included experts in TB and migration, designed a semi-structured, Spanish questionnaire with closed and openended questions, which included quantitative and qualitative methods. The questionnaire was based on previous national and international validated questionnaires (13-18), recommendations from a literature review (19), and the guidelines of the WHO “Tuberculosis PREVALENCE SURVEYS: handbook" (20).

To ensure that the survey is in accordance with the education level of the participants, the questionnaire was adapted to the education level specified in the Program of the last level of the Elementary School in Mexico (21). The questions were focused on specific topics, contained congruency control, and were limited in scope to avoid exhaustion of the participants; all to promote the reliability of the responses. A draft version was 
TABLE 1 | Demographic data.

\begin{tabular}{|c|c|c|}
\hline Variable & Observation & Frequency \\
\hline Gender (males) & 75 & 66 (88\%) \\
\hline Age in years (mean $\pm S D)$ & 75 & $32.5 \pm 1.1$ \\
\hline \multicolumn{3}{|l|}{ Migrant shelter } \\
\hline CasaNicolás & 64 & $85.3 \%$ \\
\hline Casa Santa Martha & 13 & $14.7 \%$ \\
\hline \multicolumn{3}{|l|}{ Religion } \\
\hline Catholic & 28 & $37.3 \%$ \\
\hline Protestant & 27 & $36.0 \%$ \\
\hline Other & 2 & $2.7 \%$ \\
\hline None & 13 & $17.3 \%$ \\
\hline No answer & 5 & $6.7 \%$ \\
\hline \multicolumn{3}{|l|}{ Nationality } \\
\hline Honduras & 41 & $54.6 \%$ \\
\hline Guatemala & 15 & $20.0 \%$ \\
\hline El Salvador & 12 & $16.0 \%$ \\
\hline Mexico & 3 & $4.0 \%$ \\
\hline Ecuador & 1 & $1.3 \%$ \\
\hline USA & 1 & $1.3 \%$ \\
\hline Nicaragua & 1 & $1.3 \%$ \\
\hline Venezuela & 1 & $1.3 \%$ \\
\hline \multicolumn{3}{|l|}{ Marital status } \\
\hline Single & 40 & $53.3 \%$ \\
\hline Cohabiting & 20 & $26.7 \%$ \\
\hline Married & 12 & $16.0 \%$ \\
\hline Divorced & 3 & $4.0 \%$ \\
\hline \multicolumn{3}{|l|}{ Education level } \\
\hline \multicolumn{3}{|l|}{ Elementary } \\
\hline Incomplete & 15 & $20.0 \%$ \\
\hline Complete & 25 & $33.3 \%$ \\
\hline \multicolumn{3}{|l|}{ High school } \\
\hline Incomplete & 3 & $4.0 \%$ \\
\hline Complete & 17 & $22.7 \%$ \\
\hline University or technical carrier & 9 & $11.9 \%$ \\
\hline None & 6 & $8.0 \%$ \\
\hline
\end{tabular}

piloted in a 12-person group, and pointless, duplicated, or unsuitable questions were eliminated. The resulting succinct, clear, and unequivocal questionnaire was reorganized into logical sections and standardized. The reliability of the survey was confirmed by supplying the survey questionnaire twice to the same individuals with a long enough time difference to make it highly unlikely the respondents remember their first responses. Translation from Spanish to English was used once.

\section{Procedures}

The survey was applied at the shelters during 45-to-60-min, face-to-face interviews in a relaxed atmosphere, which enabled to clarify the eventual unclear answers. Random surveys were cross-checked for continuous reliability. As a result, we collected a limited, but consistent and trustworthy amount of information, which was analyzed for the following characteristics:

1. Socio-demographic profile (age, sex, ethnicity, place of origin, education, and occupation).

2. Reasons for immigration and history of their journey (transports used, type of housing, and experiences with authorities and criminal groups).

3. Medical history.
4. Personal habits and lifestyle (tobacco, alcohol, and substance use).

5. Baseline dietary assessment.

6. Emotional well-being and social support.

7. Perceived barriers to health services and health-seeking practices.

8. Basic TB knowledge and attitudes.

In the same session, we determined anthropometric measures (height, weight, waist, and hip circumference) and blood pressure. Furthermore, we performed walk-through inspections of the shelters, to be familiar with the dormitories and the living spaces. Data collection and interpretation followed confidentiality procedures.

\section{Data Analysis}

All data were collected in an Excel Spreadsheet and subsequently fed into a Stata Software v11.0 database (College Station, TX, USA). The data were then coded and displayed according to Miles and Huberman's methods (22), before being processed through descriptive statistical analyses. Outcomes were reported as means \pm standard deviation (SD) or frequencies.

\section{Results}

In our sample, most of the immigrants were males (88\%) and their mean age was $32 \pm 11.1$ years (range: $14-60$ years); the predominant age group was from 20 to 30 years (43\%). More than half of the migrants came from Honduras (54.6\%), whereas other Central American countries (Guatemala, El Salvador, and Nicaragua) represented $37.3 \%$ of the sample (Table 1).

As a matter of fact, this sample is consistently similar to the total population of undocumented immigrants in the Monterrey Metropolitan Area during the year 2014, according to the annual report of CasaNicolás (the unique liable and available source of information on undocumented migrants). In fact, during 2014, CasaNicolás studied $87 \%$ of male immigrants including $63 \%$ from Honduras (23).

More than half of the volunteers (53\%) had only elementary school education, either complete or incomplete. One-third (25 subjects, $34 \%$ ) had high school or baccalaureate education, and only four subjects (5.3\%) had higher level education, of either a technical or professional career. Religion and marital status are reported in Table $\mathbf{1}$.

The weight, height, and body mass index (BMI) of the participants were $69.6 \pm 10.6 \mathrm{~kg}, 164.7 \pm 8.5 \mathrm{~cm}$, and $25.7 \pm 3.9$ (mean $\pm \mathrm{SD}$ ), respectively. Almost half of the subjects were overweight $(46.6 \%)$ or obese $(10.6 \%)$. None of them was underweight, despite the fact that more than half of the immigrants referred diminished or limited food intake during their journey (Table 2).

With respect to personal habits, the subjects presented good hygiene $(74.7 \%)$, but alcohol and tobacco consumptions were referred in the same proportions: $31.8 \%$ and $11.1 \%$ of males and females, respectively. Almost half of them (44.8\%) had started drinking and $80 \%$ had started smoking as teenagers. Among males, 38\% consumed both alcohol and tobacco, whereas only $11.1 \%$ of the females consumed both. Illegal drugs were 
TABLE 2 | Nutritional assessments and personal habits.

\begin{tabular}{|c|c|c|}
\hline Variable & Observation & Mean \pm SD \\
\hline \multicolumn{3}{|l|}{ Weight (kg) } \\
\hline Men & 66 & $67.8 \pm 9.1$ \\
\hline Women & 9 & $72.8 \pm 15.9$ \\
\hline \multicolumn{3}{|l|}{ Height (cm) } \\
\hline Men & 66 & $166 \pm 7.3$ \\
\hline Women & 9 & $155 \pm 9.1$ \\
\hline Body mass index & 45 & $25.7 \pm 4.0$ \\
\hline Underweighted $(<18.5)$ & 0 & 0 \\
\hline Normal weight (18.5-24.9) & 35 & $46.6 \%$ \\
\hline Overweighed (25-29.9) & 35 & $46.6 \%$ \\
\hline Obesity (>30) & 5 & $10.6 \%$ \\
\hline \multicolumn{3}{|l|}{ Waist (cm) } \\
\hline Men & 63 & $87.6 \pm 9.5$ \\
\hline Women & 9 & $100.7 \pm 11.9$ \\
\hline \multicolumn{3}{|l|}{ Hips (cm) } \\
\hline Men & 27 & $98.6 \pm 6.5$ \\
\hline Women & 6 & $107 \pm 12.4$ \\
\hline \multicolumn{3}{|c|}{ Hygiene (interviewer criteria) } \\
\hline Good & 56 & $74.7 \%$ \\
\hline Regular & 10 & $13.3 \%$ \\
\hline $\mathrm{Bad}$ & 7 & $9.3 \%$ \\
\hline No answer & 2 & $2.7 \%$ \\
\hline \multicolumn{3}{|l|}{ Alcohol } \\
\hline Men & 21 & $31.8 \%$ \\
\hline Women & 1 & $11.1 \%$ \\
\hline \multicolumn{3}{|l|}{ Tobacco } \\
\hline Men & 21 & $31.8 \%$ \\
\hline Women & 1 & $11.1 \%$ \\
\hline \multicolumn{3}{|l|}{ Drugs } \\
\hline Men & 9 & $12.0 \%$ \\
\hline Women & 1 & $1.3 \%$ \\
\hline \multicolumn{3}{|c|}{ Food intake during last month } \\
\hline Increased & 12 & $16.0 \%$ \\
\hline Equal & 22 & $29.3 \%$ \\
\hline Diminished & 35 & $46.7 \%$ \\
\hline Limited & 6 & $8.0 \%$ \\
\hline
\end{tabular}

referred in $13.6 \%$ of males and $11 \%$ of females. Of them, $66 \%$ referred using marihuana at least once and $22 \%$ referred cocaine (Table 2).

Moreover, $10.7 \%$ of men and $22.8 \%$ of women mentioned having health problems, with upper respiratory disease being the most common (15.2\%); there were trauma or lesions in $6.1 \%$, gastrointestinal disease in $4.6 \%$, and urinary disease in $3 \%$ of the sample. More women than men had medical insurance $(22.2 \%$ and $12.1 \%$, respectively). Most preferred public health services $(22.7 \%)$ and $14.7 \%$ did not seek medical attention even when sick (Table 3).

Twenty percent of women and 17\% of men had high blood pressure, and most of them declared to have had visited the healthcare system rarely. One quarter (25.3\%) affirmed having been in touch with the healthcare system two or more times over the past year, and 12 of them (16\%) once, but more than half (57.4\%) had contacted less than once over the past year. In addition to this poor pattern of healthcare seeking behavior, $14.7 \%$ referred to be close to a patient with TB, $4 \%$ referred to have acquired immune deficiency syndrome (AIDS) and 2.7\% diabetes mellitus (DM); 98.7\% referred having received the Bacillus Calmette-Guérin (BCG) vaccine (Table 3).
TABLE 3 | Health status.

\begin{tabular}{|c|c|c|}
\hline Variable & Observation & Frequency (\%) \\
\hline \multicolumn{3}{|l|}{ Health issues } \\
\hline Men & 63 & 10.7 \\
\hline Women & 8 & 22.8 \\
\hline \multicolumn{3}{|l|}{ Diseases } \\
\hline Respiratory (upper) & 10 & 15.2 \\
\hline Gastrointestinal & 3 & 4.6 \\
\hline Urinary & 2 & 3.0 \\
\hline Trauma \& Lesions & 4 & 6.1 \\
\hline Other & 3 & 4.6 \\
\hline No answer & 53 & 66.7 \\
\hline Medical insurance & 10 & 13.3 \\
\hline$\%$ of men with insurance & 8 & 12.1 \\
\hline$\%$ of women with insurance & 2 & 22.2 \\
\hline \multicolumn{3}{|c|}{ Frequency of contact with healthcare system } \\
\hline$\geq 2$ times over the past year & 19 & 25.3 \\
\hline Once over the past year & 12 & 16.0 \\
\hline $1-2$ over the past 5 years & 8 & 10.7 \\
\hline Once over the past 5 years & 11 & 14.7 \\
\hline Never in the past 5 years & 24 & 32.0 \\
\hline No data & 1 & 1.3 \\
\hline \multicolumn{3}{|c|}{$\begin{array}{l}\text { Type of health service sought when necessary } \\
\text { (various possible answers) }\end{array}$} \\
\hline Public med. in home country & 8 & 10.7 \\
\hline Public medicine in Mexico & 7 & 9.3 \\
\hline Public medicine in the US & 2 & 2.7 \\
\hline Private medicine in Mexico & 1 & 1.3 \\
\hline Migrant shelter & 3 & 4.0 \\
\hline Drugstore & 8 & 11.0 \\
\hline Self-medicated & 34 & 45.0 \\
\hline No medical attention & 11 & 14.7 \\
\hline No answer & 42 & 56.0 \\
\hline \multicolumn{3}{|l|}{ High blood pressure } \\
\hline Men & & 17.0 \\
\hline Women & & 20.0 \\
\hline \multicolumn{3}{|l|}{ Tuberculosis } \\
\hline BCG vaccine & 74 & 98.7 \\
\hline TB & 75 & 1.3 \\
\hline TB contacts & 75 & 14.7 \\
\hline \multicolumn{3}{|l|}{ Known TB contact } \\
\hline Yes & 11 & 14.7 \\
\hline No & 64 & 85.3 \\
\hline AIDS & 3 & 4.0 \\
\hline Diabetes & 2 & 2.7 \\
\hline
\end{tabular}

Participants understood that TB is a disease associated with significant morbidity and mortality, and $81.3 \%$ of the subjects considered TB a serious or very serious disease. While $17.3 \%$ mentioned vague symptoms that may relate to any kind of discomfort; only $30.7 \%$ correctly identified coughing for more than two weeks and $13.3 \%$ mentioned fever for more than one week, but none mentioned shortness of breath and weight loss. Also, $30.7 \%$ mentioned at least one wrong symptom and 33.3\% had no idea at all (Table 4). Besides, less than one-fifth (18.7\%) thought they were infected. Physicians and television were cited as the two most important sources of information on TB (Table 4).

It was the first migratory journey for $57.5 \%$ of our sample. Poverty and economic reasons had been the motive of emigration for the majority $(65.3 \%)$, violence for $22.7 \%$, family reunion for $8 \%$, and political persecution for $4 \%$. A quarter had had a previous undocumented experience and $21.3 \%$ had been deported from the US back to their home country (Table 5). For over half 
TABLE 4 | TB knowledge and perception.

\begin{tabular}{lcc}
\hline Variable & Observation & Frequency (\%) \\
\hline Can you contract TB & 75 & 18.7 \\
TB symptoms knowledge & & \\
Correct answer & 27 & 36.0 \\
Incorrect answer & 23 & 30.7 \\
Does not know & 25 & 33.3 \\
TB symptoms knowledge without misconceptions & \\
(various possible answers) & & \\
Cough >2 weeks & 23 & 30.7 \\
Fever $>1$ week & 10 & 13.3 \\
Vague symptoms & 13 & 17.3 \\
Shortness of breath & 0 & 0.0 \\
Weight loss & 0 & 0.0 \\
How serious is TB & & \\
Very serious & 45 & 60.0 \\
Serious & 16 & 21.3 \\
Not too serious & 1 & 1.3 \\
Do not know & 13 & \\
& &
\end{tabular}

TABLE 5 | Emigration Experiences.

\begin{tabular}{|c|c|c|}
\hline Variable & Observation & Frequency $(\%)$ \\
\hline \multicolumn{3}{|c|}{ Reason for emigration (various possible answers) } \\
\hline Poverty and economic reasons & 75 & 65.33 \\
\hline Violence & 75 & 22.66 \\
\hline Family reunion & 75 & 8.00 \\
\hline Political persecution & 75 & 4.00 \\
\hline Other reasons & 75 & 13.33 \\
\hline First immigration travel & 73 & 57.53 \\
\hline $\begin{array}{l}\text { Previous experience in the US as } \\
\text { an undocumented migrant }\end{array}$ & 19 & 25.33 \\
\hline $\begin{array}{l}\text { Previously deported from Mexico } \\
\text { to home country }\end{array}$ & 2 & 2.66 \\
\hline $\begin{array}{l}\text { Previously deported from the US to } \\
\text { home country }\end{array}$ & 16 & 21.33 \\
\hline Final destination & 73 & 57.53 \\
\hline USA & 40 & 53.30 \\
\hline Other & 9 & 12.00 \\
\hline No answer & 26 & 34.60 \\
\hline Place to go in the US & 68 & 90.70 \\
\hline \multicolumn{3}{|c|}{ Problems during travel (various possible answers) } \\
\hline Criminal organization & 17 & 22.60 \\
\hline Police/migration & 28 & 37.30 \\
\hline "Pollero" scam & 4 & 5.30 \\
\hline Others (civil population) & 4 & 5.30 \\
\hline None & 18 & 24.00 \\
\hline No answer & 9 & 12.00 \\
\hline \multicolumn{3}{|c|}{ Type of problem (various possible answers) } \\
\hline Violent assault & 20 & 26.66 \\
\hline Oral and physical threats & 15 & 20.00 \\
\hline Extortion & 20 & 26.66 \\
\hline Kidnapping & 6 & 8.00 \\
\hline Other kind of problems & 11 & 14.66 \\
\hline \multicolumn{3}{|c|}{ Journey funding (various possible answers) } \\
\hline Savings & 46 & 61.33 \\
\hline Temporary work & 23 & 30.66 \\
\hline Assistance (NGO/local population) & 15 & 20.00 \\
\hline Help of the shelters & 24 & 32.00 \\
\hline Other & 12 & 16.00 \\
\hline \multicolumn{3}{|l|}{ Had to borrow money? } \\
\hline Yes & 21 & 28.00 \\
\hline No & 45 & 60.00 \\
\hline No answer & 9 & 12.00 \\
\hline
\end{tabular}

of them (53\%), the journey's endpoint was the US; the majority of them (90.7\%) had an exact destination.

Almost two-thirds (64\%) reported problems during their travel, most often with the authorities (37.3\%), criminal organizations (22.7\%), and with the smugglers ("polleros"; $5.3 \%)$. Over a quarter (26.7\%) reported violent assaults and a similar percentage had suffered economic extortions. Verbal and physical threats were reported by $20 \%$ of the cases and $8 \%$ of the migrants mentioned being victims of kidnapping.

To fund their journey, $28 \%$ had borrowed money from a relative or friend and $61.3 \%$ had used their savings, but most depended on work or financial support during their trip (Table 5).

\section{Discussion}

\section{Socio-Demographic General Overview}

Undocumented migration represents $5-30 \%$ of the total immigrant population depending on the country (24). Unauthorized migration through Mexico is a major and growing issue for both Mexico and the US. The number of undocumented migrants in the US increased from around 3 or 4 million in 1993 to 12.2 million in 2007, and 11.2 million in 2012 (25). In US, the Latin American undocumented immigrants have greater problems to access the healthcare system and consequently use it less than undocumented immigrants from other parts of the world (26). However, the exact burden of undocumented immigrants in northeastern Mexico and the impact on public health are not known.

The socio-demographic profile of our population sample is in line with the available data on the 1,112 persons who attended the CasaNicolás between February and October 2014; the others' shelters have not been registered. Most immigrants were male ( $88 \%$ in our sample and $73 \%$ in the CasaNicolás register) and from Honduras ( $55 \%$ and $63 \%$, respectively). Together with other Central American countries, they represented $92 \%$ of our sample (Table 1), versus $84 \%$ of the shelter's total population.

Likewise, the reasons for migration are similar between our 75-person sample and the total population of CasaNicolás. In both the groups, poverty and economic reasons were the most frequent causes of emigration: unemployment, salaries too low to mitigate high inflation, debts, and economic crisis (65.33\% of our sample and $61 \%$ of the total CasaNicolás population). Violence was mentioned in second place (22.66\% of our sample; $7 \%$ of the total population), followed by family reunion ( 8 and $2 \%$, respectively) (Table 5).

\section{Migration and Health Interaction}

Monterrey is an economically growing city where the undocumented immigrants live temporarily and where they usually do not struggle to find a job. However, this population lacks adequate healthcare due to their immigrant status. Accordingly, their only access to healthcare generally limited to some local clinics at best, when they accept to treat them for free.

Migration and health interact and cause a decline in the general health of migrants. Undoubtedly, migrants' health depends on 
individual characteristics (gender, age, education, substance use, etc.), but it is also determined by contextual factors that cover far more than the individual health aspects. The migrant's well-being is vulnerable because of a complex interaction among the aforementioned individual characteristics, lifestyles (e.g., dehydration, habits, and food shortages), personal beliefs and attitudes, living and working conditions, and environmental characteristics (27).

Migrants face complex problems ranging from housing shortage to overcrowded shelters with poor ventilation, propitious conditions for the transmission of diseases (TB, influenza, fungi). They are also confronted with cultural and psychosocial obstacles, such as poor education and knowledge on health issues, which impede their access to health services. Another challenge is maintaining their personal safety and security within an unfriendly environment that combines food insecurity, social vulnerability in general, and overexposure to violence. When arrested by the Mexican or US migration authorities, they are usually imprisoned in overcrowded places that serve as incubators for contagious diseases and infections (28). Lastly, some of their behaviors, like untreated substance abuse and mental illness, might affect their physical health status.

Smoking, and alcohol and substance abuse are known risk factors for many diseases, including infections, because they compromise the immune response. However, adopting healthier habits may be harder for migrants than for the general population, because they have to handle much more stressful situations they rely with the use of tobacco, alcohol, and substances (29). For this reason, migrants need special counseling and medication to help them quit.

Regarding TB, we suspected TB in a volunteering migrant, but chest radiography excluded such a diagnosis. Still, TB is an excellent illustration of the complexity of healthcare issues in relation to migration. The failure to detect TB, or its late diagnosis, and the inadequate treatment follow-up in migratory TB patients precisely reflect the underlying educational/cultural factors (absence of information), economical (shortage of resources for transportation and housing), and psychosocial factors (e.g., feeling ashamed or guilty about the disease, or failure to establish a strong doctor-patient relationship), and several other social barriers (professional, familiar, etc.) (30-32).

TB prevalence is higher in socially vulnerable populations (33-35). Our study displays the high burden of health issues in the undocumented immigrant population, with pronounced conditions of social vulnerability and epidemiological risks. Undocumented migrants should be considered a focal point of health attention for being overexposed to risk factors, especially in the case of AIDS patients (4\% prevalence in our population against $0.2 \%$ in the general population of Nuevo Leon in 2013) (36) and migrants suffering diabetes (only $2.7 \%$ of our sample).

\section{The Living Conditions During Transit as a Complication to Health Access}

Since migrants usually face structural socioeconomic needs (which is the most common reason for migration), they tend not to spend money on their health. In most cases, cough, weight loss, and tiredness are considered normal and not a reason to seek medical care; $32 \%$ of our sample had no contact with any healthcare system in the past 5 years and more than half $(57.4 \%)$ had not seen a physician at least once over the past year (Table 3). Regular medical consults were uncommon under normal conditions, but are even more unlikely during their migration process. This unfortunate habit, combined with a poor knowledge on health issues, increases the delay in health seeking.

Moreover, undocumented Central American immigrants in northeastern Mexico are undoubtedly a hard-to-reach population. By definition, they are a "moving population". Their itinerant lifestyle complicates the detection of diseases and the eventual follow-up of any treatment. Their relatively bad health condition (almost one-third with a health issue of any kind and 78\% reported at least one dental problem in the past 6 months) can be explained by: (1) the accumulation of risk factors during their trip (e.g., overcrowding, malnutrition, violence; women being particularly vulnerable), (2) fear of deportation, and (3) the uncertainty about where to access healthcare.

As compared to legal immigrants, undocumented migrants are more vulnerable, face more inequality situations based on the economic, political, and institutional frameworks, and confront higher structural barriers (37). Understanding the situation of an undocumented immigrant journey enables the understanding of health inequalities. Many migrants had had limited access to the health system in their home countries due to their socioeconomic limitations on the one hand and the scarcity of community healthcare facilities on the other hand. Also during their stay in Mexico, they remain outside mainstream social systems (e.g., housing, work, health) and may suffer major social stigma and psychological issues. The same might be said for TB. Migrants not only have a greater risk of prior infection (38), but are also exposed to a high risk during the transit. For this reason, the transnational strategies developed to address the situation of TB in the border should be applied during every step of the migration process (origin, transit, temporary stays, final destination, and eventual return) and overcome territorial boundaries.

Finally, insufficient and inadequate nutrition is an important issue affecting health during the migration process. Due to insufficient economic strength and lack of physical liberty, the food consumed by migrants does not cover their dietary needs or hygiene and safety aspects (Table 2). Only during stays at temporary shelters like CasaNicolás or Casa Santa Martha, they get balanced and quantitatively sufficient food that provides adequate intake of protein, fat, and carbohydrates. A healthy diet is important to improve and guarantee an immigrant's general condition.

\section{Living with the Fear of Deportation}

In 2014, the Instituto Nacional de Migración (INM) registered 127,149 immigrants that had been presented to the Mexican migratory authorities, of which 1,477 in Nuevo Leon. Most of them were Central Americas: 119,714 (94\%) and 1,365 (92\%), respectively (39). The main concern for undocumented migrants is their legal status, as they are subject to deportation when they are caught. They are not only exposed to violence in the streets with physical and mental consequences, but they also feel the stigma of being perceived as possibly dangerous people, addicts, or burglars. Furthermore, they are far more vulnerable to be 
exploited, socially marginalized, and discriminated in everyday life, including their access to health services. It is well-known that fear of deportation withholds them from seeking health support (40-42). They usually associate the healthcare facilities with a place that exposes their undocumented status. The control of infectious disease and the decrease of community risk will only be possible by including the undocumented immigrants into the public health programs without discriminating them because of their legal status.

\section{An Overexposure to Violence}

Generally speaking, since the beginning of the "Mexican Drug War" in 2006, which empowered the criminal groups, vulnerable immigrants are one of the main victim groups, especially in the northeastern states of Tamaulipas, Coahuila, and Nuevo Leon. Organized crime has increased personal insecurity among both the undocumented migrants and Mexican emigrants.

In addition, the consciousness of their own social stigmatization discourages migrants to look for help when required. Their illegal status interferes with medical follow-up, as it implies providing personal and delicate information that may identify them as subjects for deportation. Moreover, the psychological trauma of violent episodes lived during their migration process $(64 \%$ reported some kinds of problems - i.e., extortions, assaults, and kidnapping) might provoke mistrust on the use of their personal information.

Considering, furthermore, that they are separated from their families and are without social networks to provide protection and help when needed, they are more likely to fall into alcohol and substance abuse. For all the above, we recommend offering them systematic, psychological support in the shelters. Psychological support should be focused on solving depressive disorders and socio-emotional problems and on establishing commitment to personal healthcare issues. This kind of attention would help the immigrants to understand their health issues and to consequently develop the search of medical attention when necessary and to improve the adherence to eventual treatments when sick (especially, in lengthy treatments such as the one required for TB).

\section{Socioeconomic Barriers}

Despite the fact that most of them are below the line of poverty, migrants have to develop financial strategies to cover journey expenses (mainly transport and food), even if this implies deepening the financial burden they structurally suffer. In our sample, more than half depended to a certain extent on others: $20 \%$ benefited from the assistance of the general population or social organizations that support migrants, and 32\% from the punctual help of the shelters that gave them some money to cope with the economic cost of their journey. Besides, almost one-third (28\%) had arranged a loan before their departure to cover (Table 5). This economic dependence increases their vulnerability.

Poverty and inequality are interconnected, and the most vulnerable groups represent a huge health challenge (43). Apart from their illegal status, socioeconomic barriers were the main obstacles for proper healthcare seeking in our sample. In this respect, our data confirm similar results reported for (undocumented) Latin American immigrants in the US (44). When sick, undocumented immigrants seek primarily cheap, low-quality healthcare resources before attending a healthcare center or a general hospital. They first tend to look for medical help in the immigrant shelters, and when this is not possible, they tend to self-medicate $(45 \%$ of immigrants who had a health problem during past year), or go to drugstores where they get medicines without seeing a physician (11\%), because they considered that health services are expensive and unfriendly for immigrants (Figure 1).

The absence of social support also weakens their health status, as there is no family member or friend to encourage them to go to a health center when necessary. Employment opportunities may rely on physical, mental, emotional, and spiritual wellbeing, and combined with the fact that migrants compete for obtaining the best jobs, the subsequent delay in health seeking is easily understandable. In many cases, migrants only look for medical assistance when they are completely incapacitated and suffer advanced disease (45-47). This behavior not only involves a delay in diagnosis, but also increases costs of treatment and a major public health burden (48).

Undocumented migrants are usually employed in the lowest paid jobs such as construction work, car washing, subway maintenance, food service, household cleaning, agriculture labor, and fruit picking. Especially in the construction sector, migrants are exposed to high labor risks, which are even increased because they are untrained for this kind of dangerous work and unprotected, as they have neither an accident nor a valid healthcare insurance in Mexico. Only $13.33 \%$ of the immigrants had a health insurance of any type in their home country.

Despite the fact that most migrants work in low-skilled and precarious, informal jobs, a daily wage in Nuevo Leon - the most competitive Mexican state with the highest per capita income after the capital city Mexico City and the highest average wage $(49,50)$ - may be equal to several days of pay in their home country. Although migrants identify economic factors as one of the main barriers to healthcare services, they may be unaware of the impact of education-related factors, such as knowledge and attitude, on their health-seeking behavior (51).

\section{Education, Literacy, and Health}

Previous studies on the impact of education on health practices in other Hispanic populations have shown that a high educational level is associated with better healthcare practices (52-54). In our sample, one-third had completed elementary school, $22.7 \%$ had completed high school level, and only $5.2 \%$ had studied at least one year of superior education (Table 1). Low literacy may be an obstacle in adherence to medical treatments, since the physician's written or oral recommendations may result incomprehensive. For the same reason, information campaigns may result unsuccessful (55). Unexpectedly, in our study, immigrants with a lower level of education had better information on TB symptoms $(r=0.4$; Figure 2), indicating that regular education may not be the main determinant of TB knowledge, which suggests that a specific personal experience may compensate for lack of school knowledge.

Additionally, $25.33 \%$ of the sample had had a previous experience of being undocumented in the US, and $84 \%$ of those had undergone a deportation process. However, migrants with a 


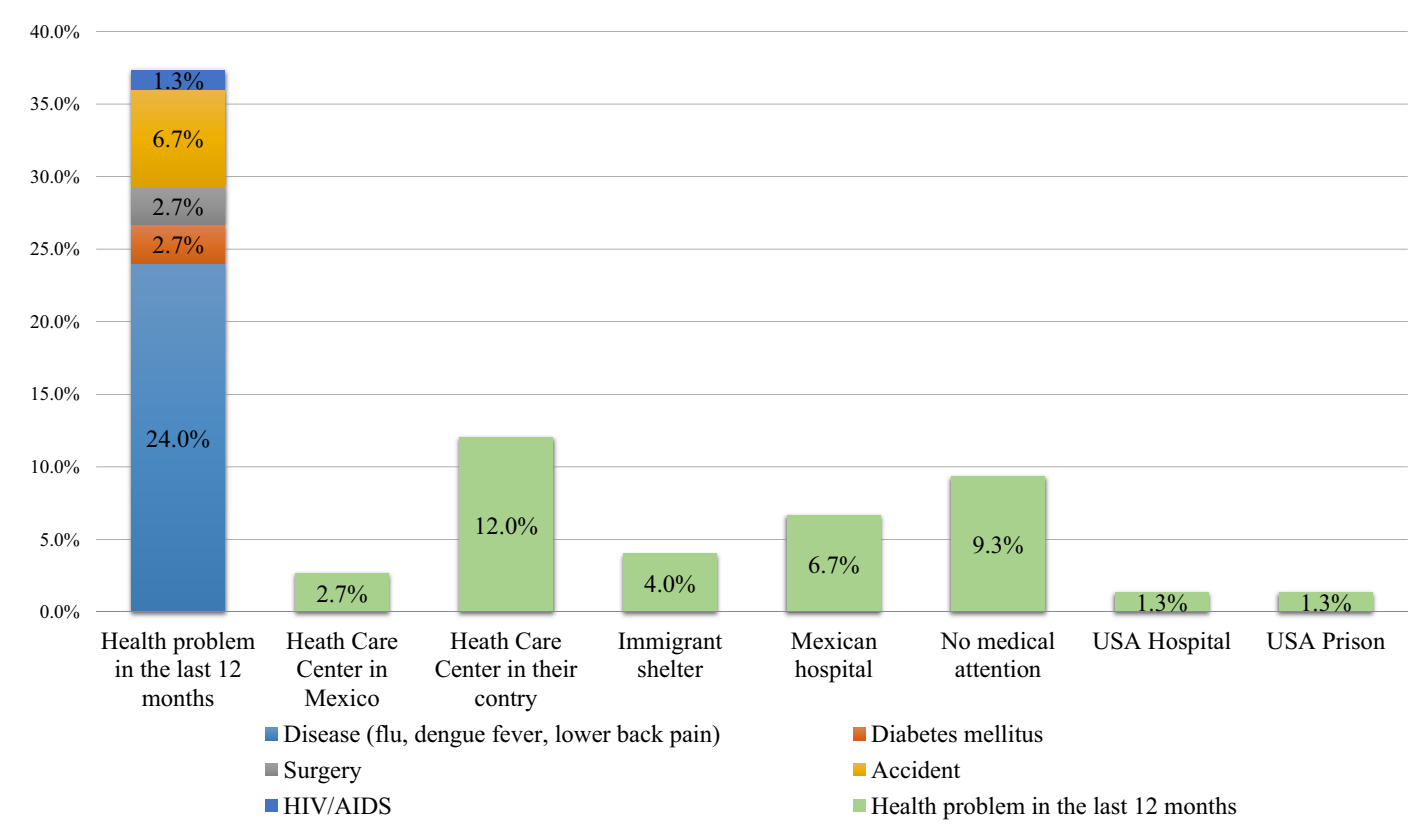

FIGURE 1 | Type of health problems in the past 12 months and medical attention received

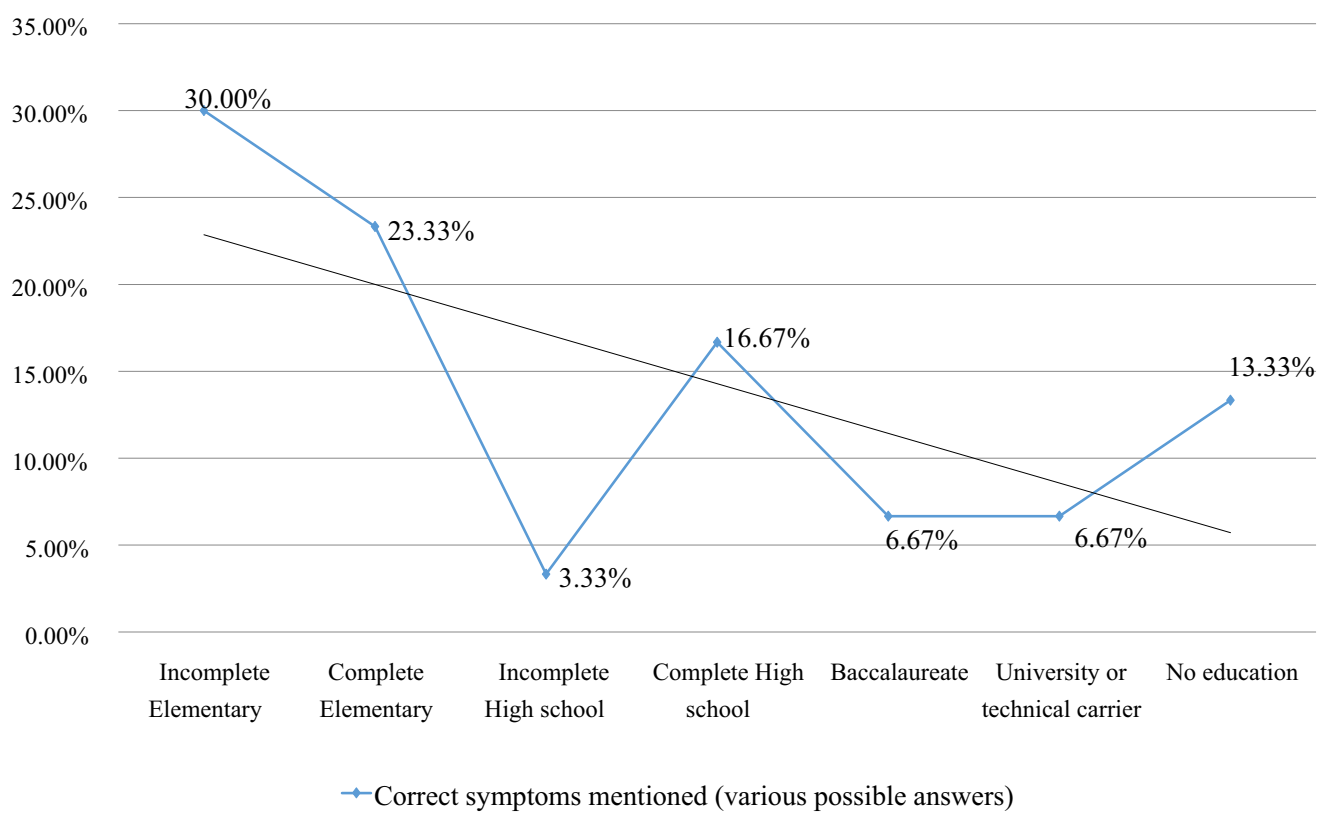

FIGURE 2 | Education level and TB symptoms knowledge.

previous deportation experience did not have more knowledge on TB ( $r=0.8$; Figure 3), even though a tuberculin test had been applied to them during the deportation process.

Considering that (1) deported migrants may intend another migration process, as evidenced by this study, (2) their knowledge on TB is insufficient (despite a previous deportation) process), and (3) their health status may be worse on a second or later intention of migration toward the US, we recommend health education, especially on $\mathrm{TB}$, to be included in the deportation process. In Mexico, TB cases are concentrated at the borders and migration routes; and in the US, the US-Mexican border also demonstrates increased TB prevalence. In most countries, $10-15 \%$ of $\mathrm{TB}$ cases were related to undocumented migrants (24). Therefore, health issues of attending migrants may diminish contagious diseases and improve the health status of the general population (56). 


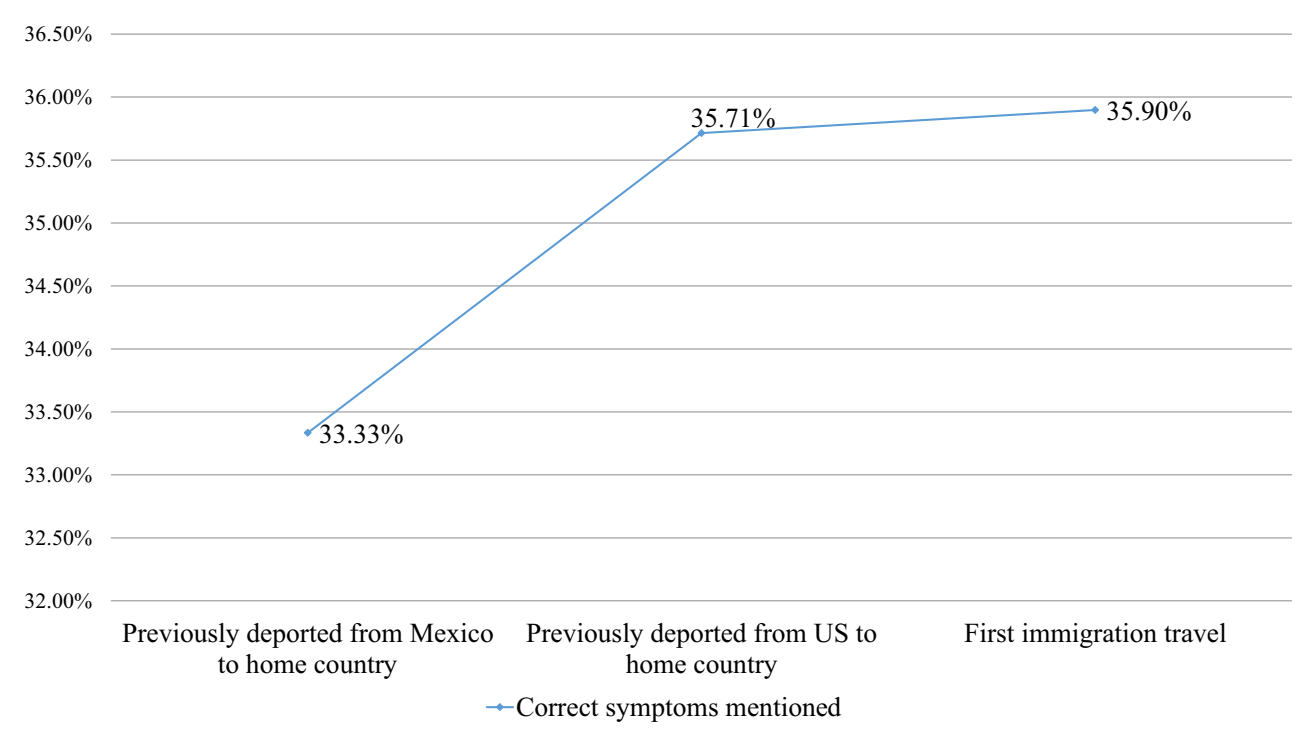

FIGURE 3 | Immigration experience and TB symptoms knowledge.

\section{Inadequate Information and Wrong Perceptions may lead to Detection Delays}

Health access is also determined by the risk perception of contracting illnesses. Our results show an inadequate education and attitude toward health issues, especially TB. While 11 persons $(14.7 \%)$ had been in contact with a TB patient and the infection was perceived as "serious" or "very serious" by most migrants (81.3\%), there was confusion about TB symptoms and a shortage of knowledge of TB. This lack of concern is preoccupying, because it seems highly unlikely they were to seek healthcare in case of presenting TB symptoms. Once again, it underscores the need for culturally adequate, affordable, and accessible healthcare.

This low level of information is consistent with previous studies on different populations, such as Latinos migrants (57), immigrant farm workers (58), and Vietnamese refugees (59). The combination of a strong belief of not being infected, a 10-20 times higher exposure to $\mathrm{TB}$, and little knowledge on $\mathrm{TB}$ symptoms forms an important reason for delayed TB detection in the migrant population delays a TB diagnosis (60-63).

For all the above reasons, adequate health education may (1) improve knowledge on TB among migrants, (2) stimulate appropriate health-seeking patterns, (3) lower risk factors, (4) increase compliance with treatment beyond the disappearance of symptoms, as is needed to treat $\mathrm{TB}$, and (5) prevent the formation of resistant Mycobacterium tuberculosis strains (64). As personal health is not the main concern of many migrants, the use of incentives and enablers could contribute to stimulate the participation commitment to health-seeking behavior.

\section{Implications and Recommendations}

The increased relative risk of latent and active TB in the undocumented population of the Monterrey Metropolitan Area represents a health threat for the general population because of the frequent and prolonged interactions between the migrants and local inhabitants. Indeed, most migrants in our sample traveled through Mexico step-by-step, or city-by-city, and they frequently lived and worked for days, weeks, or longer in the cities they crossed. A shelter is considered a short-term lodging solution upon arrival to a new city, which is replaced by another accommodation for longer stays. The average stay of the migrants in our study in Mexico was $249.69 \pm 1249.65$ days (mean \pm SD) (range: $1-11315$ days). Furthermore, $71 \%$ of them would rather stay and live in Mexico than return to their home countries in case they could not cross the Mexican-US border. Almost three quarters considered the Monterrey Metropolitan Area to be a privileged place of residence because of job opportunities and a relatively good payment.

In summary, the combination of migrants' vulnerability and inadequate health-seeking patterns, the length of their stay, and the lack of dedicated public policies may represent a health threat not only to the migrants, but also for public health in general. Our study confirms global evidence that transmission of infectious diseases, such as TB, may be intimately linked to migration issues (65-68). This constitutes a major difference with other vulnerable, but non-migrant populations, who may also suffer poverty and low educational attainment, but do have access to the social security system, for example, $77.1 \%$ of the Nuevo Leon inhabitants have social coverage, whereas undocumented migrants do not (69).

So far, there have been few publications on health issues among undocumented migrants. Further investigations on current health status and disease consequences should be encouraged. Our research provides a good starting point to identify broad outlines of public policy implications and recommendations. In addition to physical health issues, attention should be given to social-economical and emotional aspects, as the latter have a great impact on health-seeking behavior of migrants during the long, traumatic, and solitary experience of their often-violent journey. 
Migrants' health behaviors are the result of consciously planned decisions and thoughtless habits; the latter are probably harder to be modified than the former. A successful policy to improve migrants' health status and diminish the threat to public health in general needs to go beyond the current bio-medical model toward a bio-psychosocial model. To improve efficiency and circumvent migrants' self-exclusion from health services, migrants' healthcare should be compatible with the immigrants' specific characteristics: low level of health literacy, need of anonymity, and availability outside their working hours.

The migration process has a negative impact on health issues, which are reinforced by inequality between migrants and the general population in access to medical services. If securing public health would become an objective, the focus might be on the fundamental determinants of health through multi-sectoral policies involving both private and public sectors at local, national, and international levels. Preventive efforts are indispensable to foster health monitoring in the migrant population, and transnational teamwork is crucial to enforce cross-border cooperation to develop referral strategies and appropriate mechanisms for undocumented migrants beyond the local scale, and much before they arrive to the Mexican-US border.

Because of the harsh economic situation of migrants, healthcare has become a luxury for them because of its high financial cost, thus representing a powerful barrier to health-seeking behaviors. To ensure proper health access to migrants, a mechanism should be created to facilitate free access to health services, regardless of their legal status. The cost of these healthcare mechanisms should be fully covered by the local and binational authorities, given the potential implications for public health of not considering this highly vulnerable population (undetected diseases and infections, delay in diagnosis, increased costs of future treatments, transmission to healthy subjects) (70-72).

Future studies could implement Knowledge, Attitude, and Practices (KAP) analysis to deepen the understanding of the migrants' values and beliefs on the one hand and a targeted screening on several border health issues on the other hand. Actually, our research team plans to start a TB-screening campaign in summer 2015, in order to estimate the burden of latent tuberculosis infection in undocumented immigrant and to eventually offer them prophylaxis before offering treatment (73), as many countries do $(62,74-77)$. Migrants might be an exposed-to-TB

\section{References}

1. Marmot M, Friel S, Bell R, Houweling TAJ, Taylor S. Closing the gap in a generation: health equity through action on the social determinants of health. Lancet (2008) 372(9650):8-14. doi:10.1016/S0140-6736(08)61690-6

2. International Organization of Migration (IOM). World Migration Report 2010: The Future of Migration: Building Capacities for Change [Internet]. 1st ed. IOM, Imprimerie Courand et Associes (Fr) (2010). Available from: http:// publications.iom.int/bookstore/free/WMR_2010_ENGLISH.pdf

3. Cáceres CF. Interventions for HIV/STD prevention in Latin America and the Caribbean: a review of the regional experience. Cad Saúde Pública (2004) 20(6):1468-85. doi:10.1590/S0102-311X2004000600004

4. Jenks NP, Trapasso J. Lyme risk for immigrants to the United States: the role of an educational tool. J Travel Med (2005) 12:157-60. doi:10.2310/7060.2005.12302

5. Pollock KGJ, Mellor DJ, Browning LM, Wilson L, Donaghy M. Q fever in migrant workers, Scotland. Emerg Infect Dis (2007) 13(12):1963-4. doi:10.3201/eid1312.071058 group, due to their social vulnerability $(78,79)$, but we cannot address this potential problem without measuring it first.

Likewise, we aim to measure the prevalence of DM in subsequent studies, as we detected that, although most individuals in our sample suffered poor nutrition, more than half (55\%) were overweight or obese and only $44.7 \%$ had a normal BMI. This dichotomy is suggestive of a high prevalence of DM, even though only two migrants explicitly referred to suffer from DM, possibly due to an under-diagnosis of DM or a failure to detect it in this population.

In fact, the World Health Organization (WHO) announced a conditional recommendation of systematic testing of immigrants from high TB burden countries (Honduras had a TB prevalence of 74/100,000; Guatemala: 110/100,000; El Salvador: 48/100,000) (80), although, there is no clear evidence of benefits of systematically screening immigrant population (81). For this reason, we aim to generate more epidemiologic knowledge of TB burden among undocumented migrants and, afterward, on cost-effectiveness of TB-related interventions (education, detection, and treatment), in order to create better fitting strategies to migrants requirements and to prevent possible active disease (82-84).

We propose practical ways to improve health equality for migrants and diminish social exclusion through recommendations to policy-makers, like tracking and preventing disease strategies in immigrant communities, and educating and building communication; since the main reason for the spread of infections like TB is their unawareness (85). We expect that health education will increase adequate health-seeking patterns among (undocumented) migrants.

\section{Acknowledgments}

We would like to express our deepest gratitude to those who have directly facilitated this project, especially Dr. Federico Ramos, Luz Andrea Ramirez, Blanca Martinez, and Catalina Basaguren. We would also like to sincerely thank the staff of CasaNicolás and the Casa Santa Martha for always being approachable as well as all the migrants that shared their valuable experiences and time with us. Finally, we thank Irene Meester for critically reviewing and modifying the manuscript. Funding: The study was partially financed by a research grant from the University of Monterrey (Project grant \#UIN15012, www.udem.edu.mx).

6. Castillo MA. Las políticas hacia la migración Centroamericana en países de origen, de destino y de tránsito. Papeles Poblac (2000) 24:133-57.

7. Menjivar C. Fragmented Ties: Salvadoran Immigrant Networks in America. Berkeley, CA: University of California Press (2000). 113 p.

8. Anguiano-Téllez ME, Trejo-Peña AP. Vigilance and control at the U.S.-Mexico border region. The new routes of the international migration flows. Papeles Poblac (2007) 51:36-65.

9. United States-Mexico Border Health Commission (BHC). Border Lives Health Status in the United States- Mexico Border Region Border Lives Health Status in the United States-Mexico Border Region [Internet]. 1st ed. United StatesMexico Border Health Commission (BHC) (2010). Available from: http:// www.borderhealth.org/files/res_2213.pdf

10. International Organization for Migration (IOM). Glossary on Migration. Geneva: International Organization for Migration (2004).

11. Salgado-de-Snyder VN, Gonzalez-Vazquez T, Bojorquez-Chapela I, InfanteXibile C. Vulnerabilidad social, Salud y migración México-Estados Unidos. Salud Pública Méx (2007) 49:8-10. 
12. Instituto Nacional de Estadística y Geografía (INEGI). En México Somos 112 Millones 322 Mil 757 Habitantes al 12 de Junio 2010. México:Instituto Nacional de Estadística y Geografía (INEGI) (2010). 13 p.

13. Momin-Kazi A, Khalid W. Questionnaire designing and validation. J Pak Med Assoc (2012) 62(5):514-6.

14. World Health Organization (WHO). Assessing Tuberculosis Prevalence Through Population-Based Surveys. Manila: WHO Regional Office for the Western Pacific (2007).

15. World Health Organization (WHO). Advocacy, Communication and Social Mobilization for TB Control. A Guide to Developing Knowledge, Attitude and Practice Surveys. WHO Library Cataloguing-in-Publication Data (2008). Available from: http://whqlibdoc.who.int/publications/2008/9789241596176_ eng.pdf

16. Waco-McLennan Country Public Health District, TB Control Department. Tuberculosis Symptom Questionnaire. TB Control Department. Available from: http://www.waco-texas.com/userfiles/cms-healthdepartment/file/pdf/ TBsymptomQ.pdf

17. American International Health Alliance, Inc. Tuberculosis Knowledge, Attitudes \& Practices Survey. American International Health Alliance, Inc. Available from: http://www.docstoc.com/docs/103043359/KAP-Questionnaire-Moldova-eng

18. Brookfield Public Schools. Tuberculosis Risk Questionnaire. Brookfield Public Schools (2008). Available from: http://www.brookfield.k12.ct.us/sites/brookfieldctsd/files/file/file/tb_risk_questionnaire.pdf

19. Floyd S, Sismanidis C, Yamada N, Daniel R, Lagahid J. Analysis of tuberculosis prevalence surveys: new guidance on best-practice methods. Emerg Themes Epidemiol (2013) 10(10):1-13. doi:10.1186/1742-7622-10-10

20. World Health Organization(WHO). Tuberculosis PrevalenceSurveys: A Handbook. WHO Library Cataloguing-in-Publication Data (2011). Available from: http:// whqlibdoc.who.int/publications/2011/9789241548168_eng.pdf?ua=1

21. Secretaría de Educación Pública (SEP). Programas de Estudio 2011. Guía Para el Maestro. Educación Básica Primaria. Sexto Grado. 1st ed. Secretaría de Educación Pública (SEP) (2011). Available from: http://estudiaen.jalisco. gob.mx/cepse/sites/estudiaen.jalisco.gob.mx.cepse/files/sep_2011_programas_de_estudio_2011.guia_para_el_maestrosexto_grado.pdf

22. Miles MB, Huberman AM. Qualitative Data Analysis. 2nd ed. Thousand Oaks, CA: Sage Publications (1994).

23. Elizondo-Garcia F. Tercer Informe: Población Centroamericana Indocumentada en la Zona Metropolitana de Monterrey [Internet]. Centro de Derecho sHumanos (CDH): Facultad Libre de Derecho (2014). Available from: http:// www.cdh.fldm.edu.mx/assets/articulos/tercer_informe_casa_nicolas_ cdhfldm.pdf

24. Heldal E, Kuyvenhoven JV, Wares F, Migliori GB, Ditiu L, Fernandez-dela-Hoz K, et al. Diagnosis and treatment of tuberculosis in undocumented migrants in low- or intermediate-incidence countries. Int J Tuberc Lung Dis (2008) 12(8):878-88.

25. Passel JS, Cohn DV. Unauthorized Immigrant Population Rose or Fell in 21 States. Washington D.C.: Pew Research Center: Hispanic Trends (2014).

26. Ortega AN, Fang H, Perez VH, Rizzo JA, Carter-Pokras O, Wallace SP, et al. Healthcare access, use of services, and experiences among undocumented Mexicans and other Latinos. Arch Intern Med (2007) 167:2354-60. doi:10.1001/ archinte.167.21.2354

27. Wilkinson RG, Marmot MG. Social Determinants of Health. The Solid Facts. Denmark: WHO Library Cataloguing in Publication Data (2004).

28. Alexander M. The New Jim Crow: Mass Incarceration in the Age of Colorblindness. New York, NY: The New Press (2012). 336 p.

29. World Health Organization (WHO). The Union Monograph on TB and Tobacco Control: Joining Efforts to Control Two Related Global Epidemics [Internet]. WHO Library Cataloguing-in-Publication Data (2007). Available from: http://www.who.int/tobacco/resources/publications/tb_tobac_monograph. pdf

30. SINAVE/DGE/SALUD. Perfil Epidemiológico de la Tuberculosis en México [Internet]. México: Secretaría de Salud (2012). Available from: http:// www.epidemiologia.salud.gob.mx/doctos/infoepid/publicaciones/2012/ Monografias5_Tuberculosis_Mex_junio12.pdf

31. Caminero JA. Guidelines for Clinical and Operational Management of Drug-Resistant Tuberculosis [Internet]. Paris: International Union against Tuberculosis and Lung Disease (2013). Available from: http://www.theunion. org/what-we-do/publications/technical/english/mdr-tbguide_6-19-13_ web.pdf
32. World Health Organization (WHO). Multidrug-Resistant Tuberculosis (MDR-TB). Geneva: World Health Organization (WHO) (2014). 2 p.

33. Muniyandi M, Ramachandran R. Socioeconomic inequalities of tuberculosis in India. Expert Opin Pharmacother (2008) 9:1623-8. doi:10.1517/ 14656566.9.10.1623

34. Muniyandi M, Ramachandran R, Gopi PG, Chandrasekaran V, Subramani $\mathrm{R}$, Sadacharam $\mathrm{K}$, et al. The prevalence of tuberculosis in different economic strata: a community survey from South India. Int J Tuberc Lung Dis (2007) 11(9):1042-5.

35. Hargreaves JR, Boccia D, Evans CA, Adato M, Petticrew M, Porter JDH. The social determinants of tuberculosis: from evidence to action. Am J Public Health (2011) 101(4):654-62. doi:10.2105/AJPH.2010.199505

36. Centro Nacional Para la Prevención y Control VIH/SIDA (CENSIDA). La Epidemia del VIH y el Sida en México. Secretaría de Salud (2012). Available from: http://www.censida.salud.gob.mx/descargas/epidemiologia/L_E_V_S.pdf

37. Craig GM, Louise MJ, Zumla A. 'Complex' but coping: experience of symptoms of tuberculosis and healthcare seeking behaviours - a qualitative interview study of urban risk groups. BMC Public Health (2014) 14:618. doi:10.1186/1471-2458-14-618

38. World Health Organization (WHO). Global Tuberculosis Report 2014 [Internet]. WHO Library Cataloguing-in-Publication Data (2014). Available from: http:// www.who.int/tb/publications/global_report/gtbr14_executive_summary. pdf?ua=1

39. Secretaría de Gobernación (SEGOB). Eventos de Extranjeros Presentados ante la Autoridad Migratoria, Según Continente y País de Nacionalidad [Internet]. Reyes Sanabria H, Unidad de Política Migratoria (2015). Available from: http://www. gobernacion.gob.mx/es_mx/SEGOB/Extranjeros_presentados_y_devueltos

40. Cornelius WA. Death at the border: efficacy and unintended consequences of US immigration control policy. Popul Dev Rev (2001) 27(4):661-85. doi:10.1111/j.1728-4457.2001.00661.x

41. Eschbach K, Kagan J, Rodriguez N. Death at the border. Int Migr Rev (1999) 33(2):430-54. doi:10.2307/2547703

42. Asch S, Leake B, Anderson R, Gelberg L. Why do symptomatic patients delay obtaining care for tuberculosis? Am J Respir Crit Care Med (1998) 157:1244-8. doi:10.1164/ajrccm.157.4.9709071

43. Samaraweera S, Wickramage K. The challenge of establishing a migrant sensitive, rights-based approach to tuberculosis screening in Sri Lanka. Sri Lankan J Infect Dis (2014) 4(2):67-76. doi:10.4038/sljid.v4i2.6719

44. Coffman MJ, Shobe MA, O'Connell B. Self- prescription practices in recent Latino immigrants. Public Health Nurs (2008) 25:203-11. doi:10.1111/j.15251446.2008.00697.x

45. Holmes SM. An ethnographic study of the social context of migrant health in the United States. PLoS Med (2006) 3(10):e448. doi:10.1371/journal.pmed. 0030448

46. Noyes J, Popay J. Directly observed therapy and tuberculosis: how can a systematic review of qualitative research contribute to improving services? A qualitative meta-synthesis. JAdvNurs (2007) 57(3):227-43. doi:10.1111/j.13652648.2006.04092.x

47. Anibarro L, Lires JA, Iglesias F, Vilarino C, Baloria A, De Lis JM, et al. Factores sociales de riesgo para la falta de cumplimiento terapéutico en pacientes con tuberculosis en Pontevedra. Gac Sanit (2004) 18(1):38-44. doi:10.1016/ S0213-9111(04)71997-4

48. Ho MJ. Migratory journeys and tuberculosis risk. Med Anthropol Q (2003) 17(4):442-58. doi:10.1525/maq.2003.17.4.442

49. Secretaría de Trabajo y Prevención Social (STPS). Estados con el Mayor Ingreso Promedio [Internet]. Observatorio Laboral, Secretaría de Trabajo y Prevención Social (STPS) (2015). Available from: http://www.observatoriolaboral.gob.mx/swb/es/ola/Estados_con_profesionistas_ocupados_con_ mayores_ingresos_promedio_estatales

50. Instituto Mexicano para la Competitividad (IMCO). Dónde quedó la Bolita? Del Federalismo de la Recriminación al Federalismo de la Eficacia: Índice de Competitividad Estatal 2012 [Internet]. 1st ed. Diez-Morodo V, Impresos Villaflorito (2012). Available from: http://imco.org.mx/indices/documentos/ 2012_ICE_Libro_Donde_quedo_la_bolita.pdf

51. Lahelma E, Martikainen P, Laaksonen M, Aittomaki A. Pathways between socioeconomic determinants of health. J Epidemiol Community Health (2004) 58:327-32. doi:10.1136/jech.2003.011148

52. Reyes-Ortiz CA, Camacho ME, Amador LF, Velez LF, Ottenbacher KJ, Markides KS. The impact of education and literacy levels on cancer screening 
among older Latin American and Caribbean adults. Cancer Control (2007) 14(4):388-95.

53. Reyes-Ortiz CA, Freeman JL, Peláez M, Markides KS, Goodwin JS. Mammography use among older women of seven Latin American and the Caribbean cities. PrevMed (2006) 42:375-80. doi:10.1016/j.ypmed.2006.02.005

54. Sánchez-Ayéndez M, Suárez-Pérez E, Oliver-Vázquez M, Velez-Almodovar H, Cruz MN. Knowledge and beliefs of breast cancer among elderly women in Puerto Rico. P R Health Sci J (2001) 20:351-9.

55. Davis TC, Williams MV, Marin E, Parker RM, Glass J. Health literacy and cancer communication. CA Cancer J Clin (2008) 52:134-49. doi:10.3322/ canjclin.52.3.134

56. Infectious Diseases Society of America. Health-Care Barriersfor Undocumented Immigrants: Raising Tuberculosis Risk?. Science Daily (2008). Available from: www.sciencedaily.com/releases/2008/10/081029121816.htm

57. Joseph HA, Waldman K, Rawls C, Wilce M, Shrestha-Kuwahara R. TB perspectives among a sample of Mexicans in the United States: results from an ethnographic study. J Immigr Minor Health (2008) 10(2):177-85. doi:10.1007/ s10903-007-9067-5

58. Poss JE. The meanings of tuberculosis for Mexican migrant farm workers in the United States. Soc Sci Med (1998) 47(2):195-202. doi:10.1016/S0277-9536 (98)00062-8

59. Carey JW, Oxtoby MJ, Nguyen LP, Huynh V, Morgan M, Jeffery M. Tuberculosis beliefs among recent Vietnamese refugees in New York State. Public Health Rep (1997) 112(1):66-72.

60. Abarca-Tomás B, Pell C, Bueno-Cavanillas A, Guillén-Solvas J, Pool R, Roura $M$. Tuberculosis in migrant populations. a systematic review of the qualitative literature. PLoS One (2013) 8(12):e82440. doi:10.1371/journal.pone.0082440

61. Ingrosso L, Vescio F, Giuliani M, Migliori GB, Severoni S, Rezza G. Risk factors for tuberculosis in foreign-born people (FBP) in Italy: a systematic review and meta-analysis. PLoS One (2014) 9(4):e94728. doi:10.1371/journal. pone. 0094728

62. Rieder HL, Zellweger JP, Raviglione MC, Keizer ST, Migliori GB. Tuberculosis control in Europe and international migration. Eur Respir J (1994) 7(8):154553. doi:10.1183/09031936.94.07081545

63. Lillebaek T, Andersen AB, Bauer J, Dirksen A, Glismann S, Haas P, et al. Risk of Mycobacterium tuberculosis transmission in a low-incidence country due to immigration from high-incidence areas. J Clin Microbiol (2001) 39(3):855-61. doi:10.1128/JCM.39.3.855-861.2001

64. Chamanga E. Combating the spread of tuberculosis within 'hard to reach' groups. J Community Nurs (2010) 24(4):4.

65. Talbot EA, Moore M, McCray E, Binkin NJ. Tuberculosis among foreign-born persons in the United States, 1993-1998. JAMA (2006) 284(22):2894-900. doi:10.1001/jama.284.22.2894

66. Barnett ED, Walker PF. Role of immigrants and migrants in emerging infectious diseases. Med Clin North Am (2008) 92(2):1447-58. doi:10.1016/j. mcna.2008.07.001

67. Centers for Disease Control and Prevention (CDC). Trends in tuberculosis - United States, 2005. MMWR Morb Mortal Wkly Rep (2006) 55(11):305-8.

68. Hoeppner V, Baikie M, Balram C, Case C, Ellis E, Elwood RK, et al. Drugresistant tuberculosis among the foreign-born in Canada. Can Comm Dis Rep (2005) 31(4):45-52.

69. Instituto Nacional de Estadística y Geografía (INEGI). Principales Resultados de Censo Población y Vivienda 2010 [Internet]. Instituto Nacional de Estadística y Geografía (INEGI) (2010). Available from: http://www.inegi.gob.mx/ prod_serv/contenidos/espanol/bvinegi/productos/censos/poblacion/2010/ princi_result/cpv2010_principales_resultadosVI.pdf

70. Rockefeller Foundation, Save the Children, UNICEF, WHO. Universal Health Coverage: A Commitment to Close the Gap [Internet]. London: Save the Children, The Save the Children found (2013). Available from: http://www.rockefellerfoundation.org/uploads/files/57e8a407-b2fc-4a68-95db-b6da680d8b1f.pdf
71. World Health Organization (WHO). Global Tuberculosis Control: WHO Report 2013 [Internet]. Geneva: WHO Library Cataloguing-inPublication Data (2013). Available from: http://apps.who.int/iris/bitstr eam/10665/91355/1/9789241564656_eng.pdf

72. Zaman FA, Sheikh S, Das KC, Zaman GS, Pal R. An epidemiological study of newly diagnosed sputum positive tuberculosis patients in Dhubri district, Assam, India and the factors influencing their compliance to treatment. J Nat Sci Biol Med (2014) 5(2):415-20. doi:10.4103/0976-9668.136213

73. Sanz-Peláez O, Caminero-Luna J, Pérez-Arellano J. Tuberculosis e inmigración en España. Evidencias y controversias. Med Clin (2006) 126(07):259-69. doi:10.1157/13085289

74. Welshman J, Bashford A. Tuberculosis, migration, and medical examination: lessons from history. J Epidemiol Community Health (2006) 60(4):282-4. doi:10.1136/jech.2005.038604

75. Lalvani A. Spotting latent infection: the path to better tuberculosis control. Thorax (2003) 58(11):916-8. doi:10.1136/thorax.58.11.916

76. Blumberg HM, Leonard MK Jr, Jasmer RM. Update on the treatment of tuberculosis and latent tuberculosis infection. JAMA (2005) 293(22):2776-84. doi:10.1001/jama.293.22.2776

77. Chee CB, Teleman MD, Boudville IC, Do SE, Wang YT. Treatment of latent $\mathrm{TB}$ infection for close contacts as a complementary TB control strategy in Singapore. Int J Tuberc Lung Dis (2004) 8(2):226-31.

78. Denholm JT, McBryde ES, Brown GV. Ethical evaluation of immigration screening policy for latent tuberculosis infection. Aust N Z J Public Health (2012) 36(4):325-8. doi:10.1111/j.1753-6405.2012.00895.x

79. Salinas-Solano C, Altube-Urrengoetxea L, España-Yandiola PP, CapelasteguiSainz A, Quintana-Lopez JM. Tuberculosis en la población inmigrante de Bilbao. Arch Bronconeumol (2002) 38(11):506-10.

80. World Health Organization (WHO). Guidelines on the Management of Latent Tuberculosis Infection [Internet]. WHO Library Cataloguing-in-Publication Data (2015). Available from: http://apps.who.int/iris/bitstream/10665/136471/ 1/9789241548908_eng.pdf?ua=1

81. Coker R. Compulsory screening of immigrants for tuberculosis and HIV. BMJ (2004) 328(7435):298-300. doi:10.1136/bmj.328.7435.298

82. Sterling TR, Villarino ME, Borisov AS, Shang N, Bliven-Sizemore E, Hackman $\mathrm{J}$, et al. Three months of rifapentine and isoniazid for latent tuberculosis infection. N Engl J Med (2011) 365(23):2155-66. doi:10.1056/NEJMoa1104875

83. Mount F, Ferebee S. Preventive effects of isoniazid in the treatment of primary tuberculosisin children.NEnglJMed (1961) 265:713-21.doi:10.1056/NEJM196 110122651501

84. Denholm JT, McBryde ES. Management of latent tuberculosis infections in Australia and New Zealand: a review of current practice. Tuberc Res Treat (2010) 2010:284028. doi:10.1155/2010/284028

85. Young B, Rendón A, Rosas-Taraco A, Baker J, Healy M, Gross JM, et al. The effect of genetic ancestry and sociocultural factors on pulmonary tuberculosis susceptibility in northeastern Mexico. PLOS ONE (2012) 9(4):e94303. doi:10.1371/ journal.pone. 0094303

Conflict of Interest Statement: The research was conducted in the absence of any commercial or financial relationships that could be construed as a potential conflict of interest.

Copyright $\odot 2015$ Stoesslé, González-Salazar, Santos-Guzmán and Sánchez-González. This is an open-access article distributed under the terms of the Creative Commons Attribution License (CC BY). The use, distribution or reproduction in other forums is permitted, provided the original author(s) or licensor are credited and that the original publication in this journal is cited, in accordance with accepted academic practice. No use, distribution or reproduction is permitted which does not comply with these terms. 